\title{
PHYTOCHEMICAL CONSTITUENTS, ANTIOXIDANT AND ANTIMICROBIAL ACTIVITIES OF Eugenia uniflora Linn. LEAF
}

\author{
Joseph A. O. Olugbuyiro, ${ }^{1, *}$, Anuoluwapo S. Banwo ${ }^{1}$, Alaba O. Adeyemi ${ }^{2}$, \\ Olugbenga S. Taiwo ${ }^{2}$ and Oyeronke A. Akintokun ${ }^{1}$ \\ ${ }^{1}$ Department of Chemistry, Natural Products Unit, Covenant University, \\ P.M.B.1023, Ota, Nigeria. \\ ${ }^{2}$ Department of Biological Sciences, Biochemistry Unit, Covenant University, \\ P.M.B. 1023, Ota, Nigeria. \\ "E-mail: joseph.olugbuyiro@ covenantuniversity.edu.ng
}

\begin{abstract}
In this study, the leaf of Eugenia uniflora, an ornamental plant, was evaluated for its phytochemical constituents, antioxidant property and antimicrobial activity. The methanol extract of the leaf was partitioned into hexane, ethyl acetate and aqueous fractions. The antioxidant activities of the crude extract and fractions were performed using 2, 2-Diphenyl-1-picrylhydrazyl (DPPH) radical scavenging method, and $\mathrm{IC}_{50}$ values were calculated. The antimicrobial activity was tested against five bacteria strains (Pseudomonas aeruginosa, Escherichia coli, Micrococcus varians, Klebsiella pneumonia, Staphylococcus aureus) and two fungal strains (Saccharomyces cerevisiae, Aspergillus niger) using agar well diffusion method. Phytochemical screening indicated the presence of phenols, flavonoids, alkaloids, tannins, cardiac glycosides, saponin glycosides, saponins and anthraquinones in the leaf. The ethyl acetate fraction showed highest antioxidant activity $\left(\mathrm{IC}_{50}\right.$ value of $0.919 \mathrm{mg} / \mathrm{ml}$ ) compared with reference standard ascorbic acid $\left(\mathrm{IC}_{50}\right.$ value of $\left.0.859 \mathrm{mg} / \mathrm{ml}\right)$. The plant fractions demonstrated good antibacterial activities. The ethyl acetate fraction showed MIC values of $1.25 \mathrm{mg} / \mathrm{mL}$, against $P$. aeruginosa and $E$. coli; $2.50 \mathrm{mg} / \mathrm{mL}$ against $A$. niger and $5.00 \mathrm{mg} / \mathrm{mL}$ against $M$. varians, K. pneumonia and $S$. cerevisiae while the aqueous fraction had MIC values of 0.625 $\mathrm{mg} / \mathrm{mL}$ against $S$. cerevisiae; $1.25 \mathrm{mg} / \mathrm{mL}$ against $P$. aeruginosa, $M$. varians, $K$. pneumonia and $A$. niger and 2.5 $\mathrm{mg} / \mathrm{mL}$ against Escherichia coli. The hexane fraction had MIC value of $1.25 \mathrm{mg} / \mathrm{mL}$ against Staphylococcus aureus. The results indicate that Eugenia uniflora leaf is rich in natural antioxidants and bioactive compounds which may provide health benefits and serve in the management of bacterial and fungal infections.
\end{abstract}

Keywords: Eugenia uniflora, antioxidant, radical scavenging, antimicrobial, anti-infective, phytochemical

(C) RASĀYAN. All rights reserved

\section{INTRODUCTION}

Eugenia uniflora is a plant species that belongs to the Eugenia genus of Myrtaceae family. There are over 500 species in the genus, out of which 400 are indigenous plants found in Brazil ${ }^{1}$. Eugenia uniflora is a fruit-bearing plant commonly known as Surinam cherry, Brazilians ${ }^{2}$. This fruit, Eugenia uniflora has great economic importance in South American countries most especially in Brazil for its use in the food industry, for the production of frozen pulp and juice. These products have many health benefits because they contain high amounts of antioxidants like carotenoids, anthocyanins and flavonols. The phytochemical screening of the leaf of E. uniflora revealed that it contains flavonoids, tannins, phenols, saponins, triterpenes, saponin glycosides while balsams, anthracenes, volatile oils and alkaloids were absent $^{3}$. Also, in a separate study, it was reported ${ }^{4}$ that there are presence of alkaloids, tannins, phenols, flavonoids, saponins, anthraquinones, triterpenoids, terpenoids, sterols, coumarins, cardiac glycosides, resins, gum and mucilages, oxalate, anthocyanin, phlobtanins, quinones, emodins, chalcones, volatile oils, anthracenoids, anthocyanosides, thiols and acids in the leaf of $E$. uniflora. The phytochemical constituents of the leaf different solvent extracts (methanol, ethanol, chloroform, petroleum ether, ethyl acetate, acetone, aqueous cold and hot extracts) showed that its aqueous hot extract contained all the 
phytochemicals tested when compared to other solvent extracts and it also has the highest percentage yield $(48.6 \%)$.

Reactive oxygen species (ROS) has become a major concern in the field of research in biological sciences and medicine. ROS damage is a causative factor in diseases like inflammatory, cancer and neuro-degenerative diseases ${ }^{5,6}$. In the food industry, oxidation of food products can be slow down or prevented by antioxidant substances present in the fruit of $E$. uniflora ${ }^{7,8}$. ROS in the biological system has a great function in cell signaling and homeostasis but when they are present in excess due to environmental stress ${ }^{9}$, there will be significant change or damage to cell structures ${ }^{10}$. For instance, the ROS produced during normal cellular metabolism are hydroxyl radical, hydrogen peroxide, super-oxide anion and singlet oxygen ${ }^{11}$. The concentration of these ROS in the body is kept at equilibrium by a developed antioxidant regulatory system of the cells in the body. If the cell redox reactions should favor the production of the reactive oxygen species in excess that can be regulated or captured by endogenous antioxidants, it will lead to an oxidative stress and consequently result to pathological conditions and diseases like diabetes, cancer, tissue injury ${ }^{12}$. Antioxidants can be classified as water soluble and fat soluble antioxidants, enzymatic and non-enzymatic antioxidants, endogenous and exogenous antioxidants. Endogenous antioxidants are natural antioxidants present in cells. Examples are glutathione peroxidase, catalase and superoxide dismutase while exogenous anti-oxidants are derived from our diet, such as flavonoids, vitamins A, C and E, polyphenols, Phenolic acid, carotenes ${ }^{13}$. Schumacher et al. ${ }^{14}$ reported that the treatment of type-1-diabetes mellitus in non-obese diabetic (NOD) mice with aqueous extracts of E. uniflora leaf reduce the risk for diabetes as a result of the high antioxidant activity of the extract. Hepatic glutathione and serum insulin levels can be preserved and reduction in serum lipid peroxidation can be obtained in NOD mice, if treated with aqueous extract of $E$. uniflora leaf $^{14}$.

The industrial relevance of the leaves of E. uniflora has been proposed by the antimicrobial properties exhibited by the essential oil extracted from its leaves ${ }^{15}$.

The percentage composition and type of carotenoids phenolic compounds and other fundamental constituents in the fruit of E. uniflora vary depending on its geographical location, environmental and climatic condition ${ }^{16,17}$.

Therefore, the aim of this study was to evaluate the antioxidant activity of a hexane-defatted methanol extract and solvent fractions of $E$. uniflora leaf using DPPH radical scavenging method and to determine the anti-microbial activity of the plant constituents.

\section{EXPERIMENTAL}

The fresh sample of the E. uniflora leaf was collected at the premises of Covenant University, Ota, Nigeria. The plant was identified at the herbarium in the Biological Department, Covenant University, Ota Nigeria. The plant leaf was air-dried for seven days then crushed and stored in a polythene bag at room temperature for further process.

\section{Extraction}

The pulverized leaf was defatted with hexane then the marc was extracted with methanol at room temperature. The $\mathrm{MeOH}$ extract was strained, filtered and then concentrated in vacuo at $45^{\circ} \mathrm{C}$ using a rotary evaporator. The concentrate obtained was further dried in a desiccator and weighed. The methanol extract was partitioned into ethyl acetate and aqueous fractions successively using a separating funnel.

\section{Phytochemical Screening}

The plant leaf extract was screened for tannins, phenolics, flavonoids, anthraquinones, saponins, alkaloids and cardiac glycosides according to the modified standard procedures ${ }^{18,19}$.

\section{Antioxidant Assay}

The antioxidant activity of the fractionated layers and the methanol crude extracts from E. uniflora leaf was evaluated by 2, 2-diphenyl-1-picrylhydrazyl free radical scavenging method. A solution of 0.03944 $\mathrm{mg} / \mathrm{ml}$ of DPPH was prepared by dissolving $9.86 \mathrm{mg}$ of DPPH in $250 \mathrm{~mL}$ of methanol. $0.9 \mathrm{~mL}$ of the 
DPPH solution was added to $0.1 \mathrm{~mL}$ of each extract/fractionated layer in water at different concentration of $1.0,0.8,0.6,0.4,0.2$ and $0.1 \mathrm{mg} / \mathrm{mL}$ to give $1.0 \mathrm{ml}$ reaction mixture in Eppendorf tubes. The reaction was allowed to proceed at room temperature for about 30 minutes in the dark and thereafter, the absorbance was measured at $517 \mathrm{~nm}$ with spectrumlab 22 spectrophotometer (Great Medical England, $\mathrm{G}+\mathrm{M})$. A change in color of DPPH from purple to yellow was observed. Ascorbic acid served as the reference standard and it was given the same treatment as the test samples while the mixture of $0.1 \mathrm{ml}$ distilled water and $0.9 \mathrm{ml}$ DPPH solution (blank) was used as the negative control. This experiment was carried out in triplicate and the percentage inhibition was evaluated as follows:

$$
\text { Percentage Inhibition }=\left(\frac{A c-A s}{A c}\right) \times \frac{100}{1}
$$

Where Ac was the absorbance of the negative control and As was the absorbance of the test sample or reference standard sample (positive control). Hence, the concentration needed ( $\mathrm{IC}_{50}$ value) to inhibit $50 \%$ of the DPPH was calculated.

\section{Antimicrobial Assay}

Antimicrobial activity was tested against the following clinical strains of micro-organisms Micrococcus varians, Escherichia coli, Pseudomonas aeruginosa, Serratia spp; Staphylococcus aureus, and Saccharomyces cerevisiae. Agar well diffusion method ${ }^{20,21}$ was engaged in the experiment. Organisms were maintained in slants of nutrient agar for the bacteria and the fungi were maintained in slants of Sabouraud Dextrose Agar (SDA). Ampicillin and Tioconazole were used as reference drugs for bacteria and fungi respectively. The extracts were allowed to diffuse into the agar media for 1 hour. Then the plates were incubated at $37{ }^{\circ} \mathrm{C}$ for $24 \mathrm{~h}$ for the bacteria while the plates for fungi were incubated at $25{ }^{\circ} \mathrm{C}$ for 3 days. Three replicates were made for each condition. Zone of inhibitions was measured in millimetres and the average values were calculated and recorded, then Activity Index was calculated. MIC test was conducted on plant fractions that showed good susceptibility activities.

\section{Statistical Analysis}

Values were expressed as a mean \pm standard error and Tukey's post hoc test was carried to analyze the significance of the difference between different groups, using the statistical analysis software package SPSS (Version 13). Values with $P<0.05$ were regarded as significant.

\section{Phytochemical Screening}

\section{RESULTS AND DISCUSSION}

The phytochemical analysis of the leaf of E. uniflora showed (Table-1) the presence of phenols, tannins, cardiac glycosides, saponins, saponin glycosides, flavonoids, alkaloids and anthraquinones. The previous work of Daniel ${ }^{4}$ agrees with the finding of this study.

Table-1: Classes of Secondary Metabolites in Eugenia uniflora leaf

\begin{tabular}{|c|c|}
\hline Phytochemical & Intensity \\
\hline Phenols & +++ \\
\hline Flavonoids & +++ \\
\hline Alkaloids & +++ \\
\hline Tannins & +++ \\
\hline Cardiac glycosides & ++ \\
\hline Saponin glycosides & +++ \\
\hline Saponins & ++ \\
\hline Anthaquinones & ++ \\
\hline
\end{tabular}

\section{Antioxidant Activity}

There was a decrease in absorbance of DPPH solution with each sample of the fractions of E. uniflora leaf extract because of the capacity of the antioxidant present in the sample to scavenge (donate 
hydrogen) the stable DPPH free radical and hence convert it to a reduced form known as 2,2-diphenyl-1picrylhydrazines, $\mathrm{DPPH}-\mathrm{H}^{22}$. One-way ANOVA analysis reveals significant difference between mean percentage inhibitions of the plant fractions (Table-2) as compared with both positive and negative controls $(\mathrm{P}<0.05)$. Subsequently, the Tukey's Simultaneous test at $95 \%$ Confidence interval shows a significant difference between the mean percentage inhibition values of ethyl acetate extract (EEU), hexane extract (HEU), methanol crude extract (MEU) and Ascorbic acid (positive control) but no significant difference between AEU and Ascorbic acid. Figure-1 shows the percentage inhibition against the concentration of each extract as evaluated graphically by linear regression. The $\mathrm{IC}_{50}$ value (Table-3) of the ascorbic acid was $0.859 \mathrm{mg} / \mathrm{ml}$ while the $\mathrm{IC}_{50}$ values of methanol crude extract, hexane, ethyl acetate, and aqueous fractions were $1.019 \mathrm{mg} / \mathrm{ml}, 1.229 \mathrm{mg} / \mathrm{ml}, 0.919 \mathrm{mg} / \mathrm{ml}$ and $1.056 \mathrm{mg} / \mathrm{ml}$. respectively. It was observed that the free radical scavenging activity of ethyl acetate portion of $E$. uniflora leaf extract compared favorably with that of ascorbic acid in this study. The ethyl acetate fraction had the highest antioxidant property. This agrees with the deduction made in other studies which revealed that the ethyl acetate fraction of E. uniflora leaf extract contains higher antioxidant potential compared to the butanol and aqueous fractions of the same extract as a result of higher polyphenols content in ethylacetate fraction ${ }^{23}$. Likewise, polyphenolic compounds have been found to possess a wide range of bioactivity potential and have been indicated by the high activity of fruit extract of Eugenia uniflora in DPPH antioxidant assay compared to the activities of fruit extracts of over thirty edible tropical fruits ${ }^{24}$.

Table-2: Percentage Inhibitions of Extracts of Eugenia uniflora Compared with Ascorbic Acid Concentration $\%$ Inhibition

\begin{tabular}{c|c|c|c|c|c}
\hline & HEU Extract & $\begin{array}{c}\text { EEU } \\
\text { Extract }\end{array}$ & AEU Extract & MEU Extract & Ascorbic acid \\
\hline 1.00 & $43.4 \pm 0.0$ & $54.4 \pm 0.0$ & $48.9 \pm 0.0$ & $49.1 \pm 0.0$ & $56.2 \pm 0.0$ \\
\hline 0.80 & $38.0 \pm 0.1$ & $43.4 \pm 0.1$ & $43.4 \pm 0.0$ & $38.4 \pm 0.1$ & $47.1 \pm 0.0$ \\
\hline 0.60 & $32.5 \pm 0.0$ & $32.5 \pm 0.0$ & $38.9 \pm 0.2$ & $26.4 \pm 0.0$ & $39.8 \pm 0.0$ \\
\hline 0.40 & $27.0 \pm 0.3$ & $21.5 \pm 0.1$ & $34.3 \pm 0.1$ & $15.7 \pm 0.1$ & $30.7 \pm 0.1$ \\
\hline 0.20 & $21.5 \pm 0.1$ & $10.6 \pm 0.2$ & $28.8 \pm 0.3$ & $5.0 \pm 0.2$ & $23.4 \pm 0.1$ \\
\hline 0.10 & $17.9 \pm 0.1$ & $5.1 \pm 0.1$ & $27.0 \pm 0.1$ & $0.3 \pm 0.0$ & $19.7 \pm 0.1$ \\
\hline
\end{tabular}

Key: HEU = hexane extract, EEU = ethyl acetate extract, AEU = aqueous extract,

$\mathrm{MEU}=$ methanol crude extract. Values are means of quadruplicate readings (mean \pm S.D)

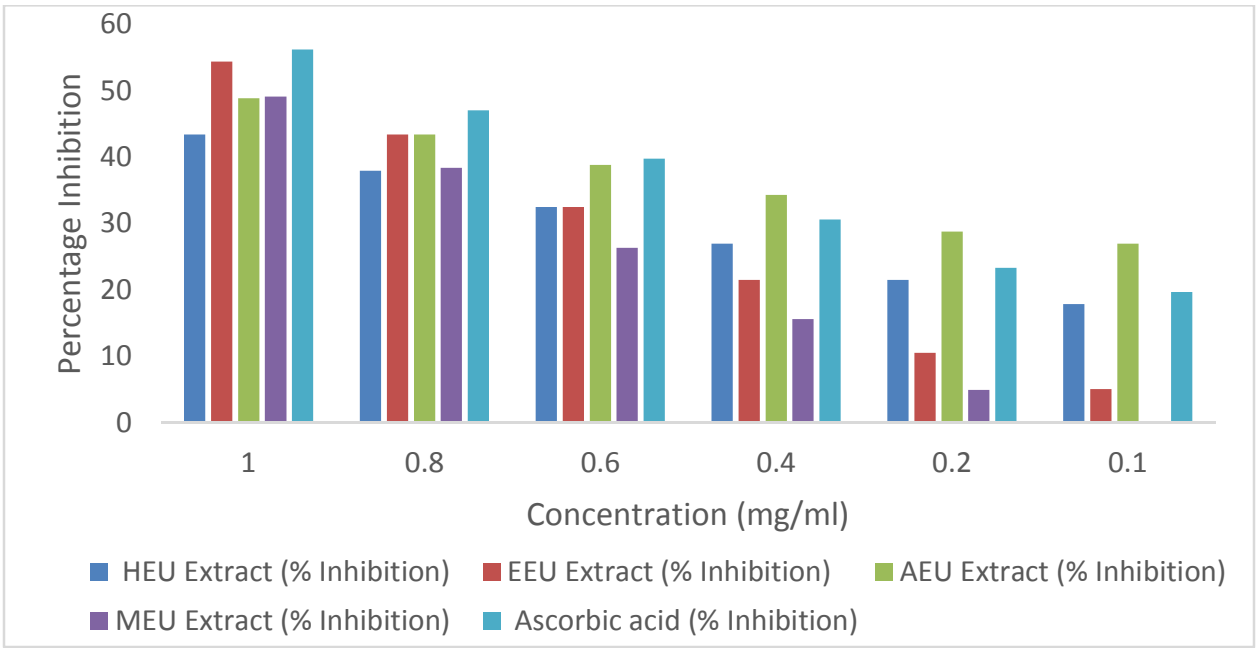

Fig.-1: Percentage Inhibition vs Concentration

\section{Antimicrobial Activity}

The preliminary antimicrobial screening (Table-4) showed that the crude methanol extract of E. uniflora leaf demonstrated good antimicrobial activity against the test pathogens (Pseudomonas aureginosa, Micrococcus varians, Klebsiella pneumonia, Saccharomyces cerevisiae and Aspergillus niger). The 
activity of the extract against the bacteria was found to be lowest in Pseudomonas aeruginosa $(\mathrm{ZI}=13$ $\mathrm{mm}, \mathrm{AI}=0.65)$ but highest in Micrococcus varians $(\mathrm{ZI}=20 \mathrm{~mm}, \mathrm{AI}=0.98)$, followed by Klebsiella pneumonia $(\mathrm{ZI}=17.50 ; \mathrm{AI}=0.92)$ when compared with the reference drug. The crude extract showed high antifungal activity against Saccharomyces cerevisiae $(\mathrm{ZI}=24 \mathrm{~mm}, \mathrm{AI}=1.6)$. Hence, the extract was fractionated to yield hexane, EtOAC and aqueous layers i.e. HEU, EEU and AEU respectively. Table-5 and Figure-2 presented the antimicrobial activities of the leaf fractions of E. uniflora. The HEU was the only fraction active against $S$. aureus Table-5 with ZI of $20 \mathrm{~mm}$ (1.05 activity index). However, HEU was inactive against Escherichia coli, Klebsiella pneumonia, and Aspergillus niger. Both EEU and AEU fractions had significant inhibition $(\mathrm{P}<0.05)$ against the growth of the test microorganisms Table-5 and Figure-2 EEU fraction was the most active against three bacteria strains ( $P$. aeruginosa, E. coli, $K$. pneumonia), and one fungal strain (A. niger), while AEU is the most active fraction against two bacteria (M. varians, and $S$. aureus). The two plant fractions showed good antifungal and antibacterial activities against Saccharomyces cerevisiae (EEU: $\mathrm{ZI}=23.50 \mathrm{~mm} ; \mathrm{AI}=1.57$ and $\mathrm{AEU}: \mathrm{ZI}=23.50 ; \mathrm{AI}=1.57$ ) and Micrococcus varians (EEU: $\mathrm{ZI}=21 \mathrm{~mm} ; \mathrm{AI}=1.02$ and $\mathrm{AEU}: \mathrm{ZI}=24.50 \mathrm{~mm} ; \mathrm{AI}=1.20$.) respectively. This implies that EEU and AEU contain bioactive compounds which are very potent against the two pathogens when compared with the reference drugs cloxacillin and fluconazole respectively.

Table-3: Antioxidant Activity $\left(\mathrm{IC}_{50}\right)$ of the Extracts of Eugenia uniflora leaf

\begin{tabular}{c|c}
\hline Extract/Fractions & $\mathrm{IC}_{50}$ Values $(\mathrm{mg} / \mathrm{ml})$ \\
\hline HEU & 1.229 \\
\hline EEU & 0.919 \\
\hline AEU & 1.056 \\
\hline MEU & 1.019 \\
\hline Ascorbic acid & 0.859
\end{tabular}

$\mathrm{HEU}=$ hexane extract; $\mathrm{EEU}=\mathrm{EtOAC}$ extract $; \mathrm{AEU}=$ aqueous extract $; \mathrm{MEU}=$ methanol crude extract; Ascorbic acid $=$ Standard

The test drugs that had zone of inhibition, $\mathrm{ZI} \geq 20 \mathrm{~mm}$ were considered active and subsequently subjected to MIC test. The MIC values of the plant fractions are shown in Tables-6 and 7; the values range from $0.625 \mathrm{mg} / \mathrm{mL}$ to $5.00 \mathrm{mg} / \mathrm{mL}$. The hexane fraction (HEU) had MIC value of $1.25 \mathrm{mg} / \mathrm{mL}$ (Table-7) against $S$. aureus. The EEU test drug showed the lowest MIC value of $1.25 \mathrm{mg} / \mathrm{mL}$ against Pseudomonas aeruginosa and Escherichia coli. The AEU had MIC values of $0.625 \mathrm{mg} / \mathrm{mL}$ against $S$. cerevisiae, 1.25 $\mathrm{mg} / \mathrm{mL}$ against $P$. aeruginosa, $M$. varians, $K$. pneumonia and $A$. niger and $2.50 \mathrm{mg} / \mathrm{ml}$ against E.coli. This results (Table-6) show that AEU fraction exhibited higher activity at low concentration (MIC range: $0.625 \mathrm{mg} / \mathrm{mL}-2.50 \mathrm{mg} / \mathrm{mL}$ ) compared to EEU fraction (MIC values range: $1.25 \mathrm{mg} / \mathrm{mL}-5.0 \mathrm{mg} / \mathrm{mL}$ ).

Table-4: Antimicrobial Activity of Methanol Crude Extract of E. uniflora leaf.

\begin{tabular}{c|c|c|c}
\hline Microorganism & $\begin{array}{c}\text { Zone of Inhibition } \\
(\mathrm{mm})\end{array}$ & Activity Index \\
\cline { 3 - 4 } Bacteria & & Cloxacillin $(5.0 \mu \mathrm{g})$ & \\
\hline Pseudomonas aeruginosa & $13.0 \pm 0.25$ & 20.0 & 0.65 \\
\hline Escherichia coli & 0.0 & 19.0 & - \\
\hline Micrococcus varians & $20.0 \pm 0.27$ & 20.50 & 0.98 \\
\hline Klebsiella pneumonia & $17.5 \pm 0.15$ & 18.00 & 0.97 \\
\hline Staphylococcus aureus & $15.5 \pm 0.00$ & 19.00 & 0.82 \\
\hline Fungi & & Flucanazole $(1.0 \mathrm{mg})$ & \\
\hline Saccharomyces cerevisiae & $24.0 \pm 0.20$ & 15.00 & 1.6 \\
\hline Aspergillus niger & $13.0 \pm 0.50$ & 13.00 & 1.00 \\
\hline
\end{tabular}

Key: ZI = zone of inhibition $(\mathrm{mm}), \mathrm{ZI}$ were expressed as mean \pm standard deviation of three replicates; AI = activity Index $=$ ZI of test sample/ ZI of standard. Extract concentration $=20.00 \mathrm{mg} / \mathrm{mL}$; - = nil 
RASĀYAN J. Chem.

Vol. 11 | No. 2 |798-805 | April - June | 2018

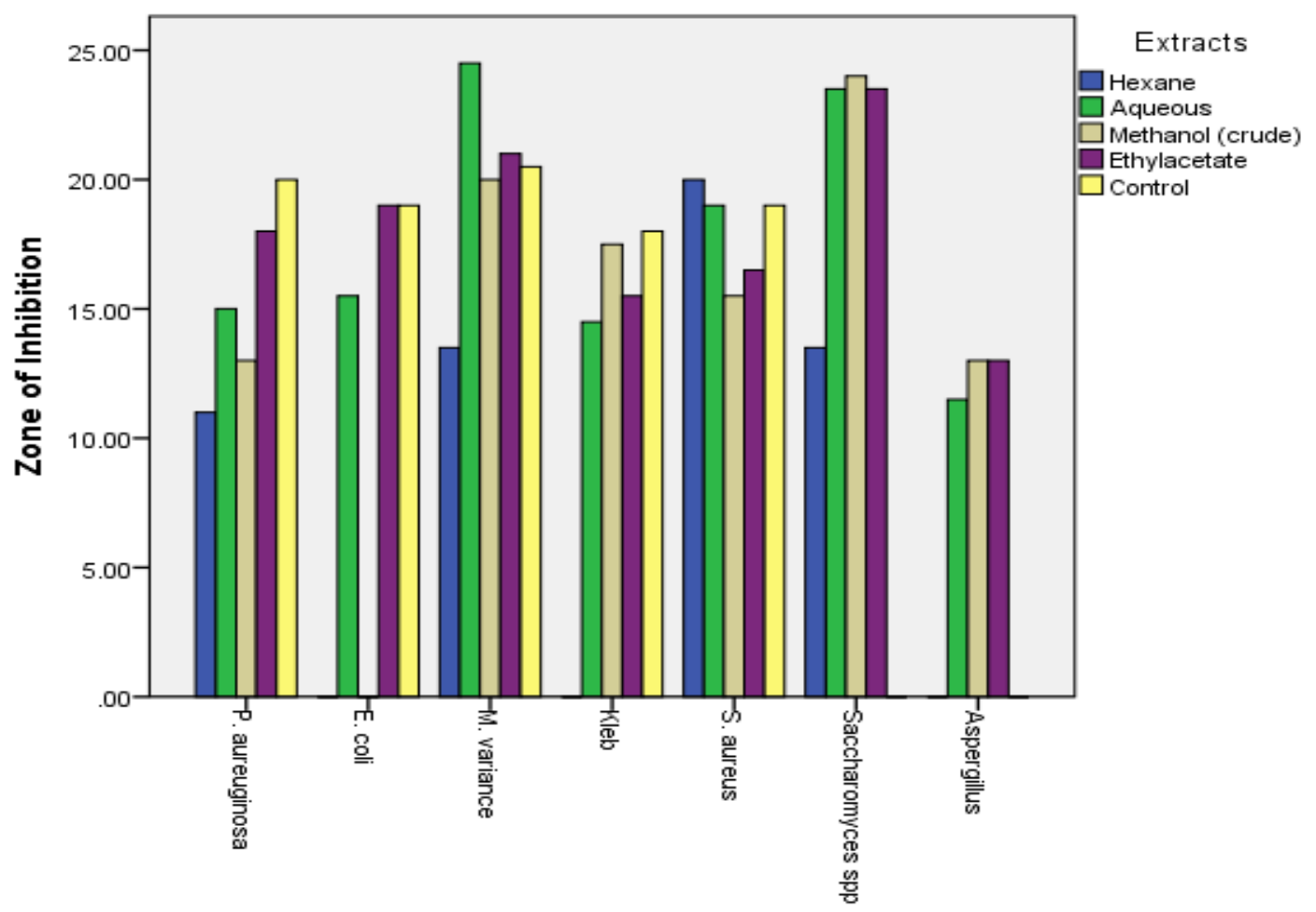

Micro-organisms

Figure-2: Showing Zone of Inhibitions of the Plant Extract/Fractions Against the Test Pathogens

Table-5: Antimicrobial Activity of E. uniflora leaf Fractions.

\begin{tabular}{c|c|c|c|c|c}
\hline Microorganism & & \multicolumn{3}{|c|}{ Plant fractions } & Standard \\
\hline Bacteria & & HEU & EEU & AEU & Cloxacillin $(5 \mu \mathrm{g})$ \\
\hline Pseudomonas aureuginosa & ZI & $11.0 \pm 0.20$ & $18.0 \pm 0.15$ & $15.0 \pm 0.20$ & 20.0 \\
\hline & AI & 0.55 & 0.90 & 0.75 & 19.0 \\
\hline Escherichia coli & ZI & 0.0 & $19.0 \pm 0.00$ & $15.5 \pm 0.12$ & 20.5 \\
\hline Micrococcus varians & AI & - & 1.00 & 0.82 & 18.0 \\
\hline & ZI & $13.5 \pm 0.35$ & $21.0 \pm 0.10$ & $24.5 \pm 0.15$ & \\
\hline Klebsiella pneamoniea & AI & 0.66 & 1.02 & 1.20 & 19.0 \\
\hline ZI & 0.0 & $15.5 \pm 0.15$ & $14.5 \pm 0.00$ & \\
\hline Staphylococcus aureus & AI & - & 0.86 & 0.81 & \\
\hline ZI & $20.0 \pm 0.00$ & $16.5 \pm 0.12$ & $19.0 \pm 0.33$ & \\
\hline Faccharomyi & AI & 1.05 & 0.87 & 1.00 & Flucanazole $(1.0 \mathrm{mg})$ \\
\hline Aspergillus niger & & & & & 15.0 \\
\hline & ZI & $13.5 \pm 0.25$ & $23.5 \pm 0.15$ & $23.5 \pm 0.12$ & 13.0 \\
\hline & AI & 0.90 & 1.57 & 1.57 & \\
\hline & II & 0.0 & $13.0 \pm 0.00$ & $11.5 \pm 0.00$ & \\
\hline
\end{tabular}

Key: ZI were expressed as mean \pm standard deviation of three replicates; $\mathrm{AI}=$ activity Index $=$ ZI of test sample/ ZI of standard. Extract concentration $=20.00 \mathrm{mg} / \mathrm{mL}$. - = nil.

Table-6: MIC Results of Eugenia uniflora leaf Fractions

\begin{tabular}{c|c|c|c|c|c|c|c}
\hline \multirow{2}{*}{$\begin{array}{c}\text { Plant } \\
\text { Extract }\end{array}$} & $\begin{array}{c}\text { Concentration } \\
(\mathrm{mg} / \mathrm{ml})\end{array}$ & \multicolumn{5}{|c}{ Test organism Zone of Inhibition $(\mathrm{mm})$} \\
\cline { 3 - 7 } & & P. aeruginosa & E. coli & M. varians & $\begin{array}{c}\text { K. } \\
\text { pneumonia }\end{array}$ & $\begin{array}{c}\text { S. } \\
\text { cerevisiae }\end{array}$ & $\begin{array}{c}\text { A. } \\
\text { niger }\end{array}$ \\
\hline EEU & 20.00 & -- & -- & -- & -- & -- & -- \\
\hline & 10.00 & -- & -- & -- & -- & -- & -- \\
\hline
\end{tabular}


RASĀYAN J. Chem.

Vol. 11 | No. 2 |798 - 805 | April - June | 2018

\begin{tabular}{c|c|c|c|c|c|c|c}
\hline & 5.00 & -- & -- & $\mathrm{O}^{+}$ & $\mathrm{O}^{+}$ & $\mathrm{O}^{+}$ & -- \\
\hline & 2.50 & -- & -- & + & + & + & $\mathrm{O}^{+}$ \\
\hline & 1.25 & $\mathrm{O}^{+}$ & $\mathrm{O}^{+}$ & + & + & + & + \\
\hline $\mathrm{AEU}$ & 20.00 & -- & -- & -- & -- & -- & -- \\
\hline & 10.00 & -- & -- & -- & -- & -- & -- \\
\hline & 5.00 & -- & -- & -- & -- & -- & -- \\
\hline & 2.50 & -- & $\mathrm{O}^{+}$ & -- & -- & -- & -- \\
\hline & 1.25 & $\mathrm{O}^{+}$ & + & $\mathrm{O}^{+}$ & $\mathrm{O}^{+}$ & -- & $\mathrm{O}^{+}$ \\
\hline
\end{tabular}

Key: $\mathrm{O}+=\mathrm{MIC}$ value; $\quad(+)=$ growth

$(-)=$ no growth

Table-7: The MIC Result of Hexane Extract of E. uniflora leaf.

\begin{tabular}{|c|c|c|}
\hline \multirow[t]{2}{*}{ Plant Extract } & \multirow{2}{*}{$\begin{array}{l}\text { Concentration } \\
(\mathrm{mg} / \mathrm{ml})\end{array}$} & Staphylococcus aureus \\
\hline & & Zone of Inhibition (mm) \\
\hline \multirow[t]{6}{*}{ HEU } & 20.00 & -- \\
\hline & 10.00 & -- \\
\hline & 5.00 & -- \\
\hline & 2.50 & -- \\
\hline & 1.25 & $\mathrm{O}^{+}$ \\
\hline & 0.625 & + \\
\hline
\end{tabular}

Key: O+ = MIC value; $\quad(+)=$ growth $\quad(-)=$ no growth

\section{CONCLUSION}

Natural antioxidants of plants origin have many medicinal values as well as nutraceuticals and phytoceuticals uses. In this study, Eugenia uniflora leaf has been found rich in phenol and flavonoid contents and its extracts exhibit high antioxidant activity. Consumption of Eugenia uniflora leaf as vegetable may serve as health benefit by scavenging and reducing free radicals in the body. The findings justify its use in folk medicine for treating inflammatory diseases, high blood pressure, hypertension etc. Also, the good antimicrobial property demonstrated by the plant sample would also provide anti-infective use to the health care.

\section{ACKNOWLEDGMENT}

The authors are thankful to the management of Covenant University for providing the necessary facilities to carry out the research work.

\section{REFERENCES}

1. H. Lorenz and F.J.A. Matos, Plantas Medicinals no Brasil Nativas e Exóticas, $2^{\text {nd }}$ edition, Institute to platarum de Estudos da Flora Ltda: Nova Odessa-sp, Brasil, p. 512(2002).

2. P. Weyerstahi, H. Marschall-Weyerstahi, C. Christiansen, O. Oguntimehin, A.O. Adeoye, Planta Médica 54(6), 546(1988), DOI: 10.1055/s-2006-962544.

3. R.U. Okoh-Esene, J.H. Suleiman and S.A. Thomas, Journal of Natural Products Plant Resources, 1 (4),1(2011).

4. G. Daniel and S. Krishnakumari, Int. J. Pharm. Bio. Sci., 6(1), 1008(2015), DOI: 10.1186/14752875-12.

5. R.A. Jacob and B.J. Burri, The American Journal of Clinical Nutrition, 63(6), 985S (1996), DOI: 10.1093/ajcn/63.6.985.

6. F. Bakkali, S. Averbeck, D. Averbeck and M. Idaomar, Food Chem Toxicol., 46(2), 446(2008), DOI:10.1016/j.fct.2007.09.106.

7. F. Shahidi and M. Naczk, Phenolics in food and nutraceuticals, F. Shahidi and M. Naczk (Eds), Boca Raton: CRC Press, pp.397-438(2004).

8. M.B. Hossaina, N.P. Bruntonb, C. Barry-Ryana, A.B. Martin-Dianaa, and M. Wilkinsonc, Rasayan J. Chem, 1(4), 751(2008), DOI:10.21427/D7105D. 
9. T.P.A. Devasagayam, J.C. Tilak, K.K. Boloor, K.S. Sane, S.S. Ghaskadbi and R.D. Lele, Journal of Association of Physicians of India, 52, 794(2004), DOI: 10.1097/01.

10. P. Sugita, S. Arya, A. Ilmiawati and B. Arifin, Rasayan J. Chem., 10(3), 707(2017), DOI:10.7324/RJC.2017.1031716.

11. D.M. Miller, G.R. Buetmer and S.D. Aust, Free Radical Biology \& Medicine, 8, 95(1990).

12. B. Halliwell, M.A. Murcia, S. Chirico, O.I. Aruoma, Critical Reviews in Food Science and Nutrition, 35, 7(1995), DOI: 10.1080/10408399509527712.

13. A.C. Maritim, R.A. Sanders, J.B. Watkins, Journal of Biochemical and Molecular Toxicology, 17, 23(2003), DOI: 10.1002/jbt.10056.

14. N.S.G. Schumacher, T.C. Colomeu, D. Figueiredo, V.C. Carvalho, C.B.B. Cazarin, M.A. Prado, L.M.M. Meletti and R.L. Zollner, Antioxidants 4, 662(2015), DOI: 10.3390/antiox4040662.

15. F.N. Victoria, E.J. Lenardão, L. Savegnago, G. Perin, R.G. Jacob, D. Alves, W.P. Silva, A.S Motta and P.S. Nascente, Food and Chemical Toxicology, 50, 2668(2012), DOI: 10.1016/j.fct.2012.08.005.

16. K. Robards, M. Antolovich, Analyst 122, 11R (1997), DOI: 10.1039/A606499J.

17. S.A. Aherne and N.M. O'brien, Nutrition, 18(1), 75(2002), DOI: 10.1016/S0899-9007(01)00695-5.

18. J.A.O. Olugbuyiro, Phytochemical Guides:Laboratory manual for natural products research. Department of Chemistry, Covenant University, Ota. pp.1-4(2012).

19. W.C. Evans, Trease and Evans' Pharmacognosy $16^{\text {th }}$ edition, Saunders Company Ltd. London, (2006).

20. J.A.O. Olugbuyiro, O.S. Taiwo, O.T. Olaniyi and F.A. Obi, Chemical Society of Nigeria Book of Proceedings of an $39^{\text {th }}$ Annual International Conference, Workshop and Exhibition held at Rivers State, Nigeria, pp 1-5(2017).

21. J.A.O. Olugbuyiro, O.E. Omotosho, O.S. Taiwo, F.O.Ononiwu, A.S. Banwo, O.A. Akintokun, O.S. Obaseki and O.M. Ogunleye. Antimicrobial Activities and Phytochemical Properties of Annona muricata Leaf. Covenant Journal of Physical \& Life Sciences, 5(2), 42(2017).

22. J.J.B. Jandú, L.C.N. Silva, A.P.C. Pereira, R.M. Souza, C.A.S. Júnior, R.C.B.Q. Figueiredo, J.M. Araújo, M.T.S. Correia and M.V. Silva, Journal of Medicinal Plants Research 7(8), 413(2013), DOI: $10.5897 / J M P R 12.681$.

23. E.O. Figueirôa, L.C.N. Silva, C.M.L. Melo, J.K.A.L. Neves, N.H. Silva, V.R.A. Pereira and M.T.S. Correia, The Scientific World Journal, 125027,7(2013), DOI: 10.1155/2013/125027.

24. K.A. Reynertson, M.J. Basile and E.J. Kennelly, Ethnobotany Research \& Application, 3, 025(2005), DOI: $10125 / 151$.

[RJC-1823/2018] 